\title{
Perturbation of Intracellular Calcium and Hydrogen Ion Regulation in Cultured Mouse Hippocampal Neurons by Reduction of the Sodium Ion Concentration Gradient
}

\author{
Robert A. Koch ${ }^{1,2}$ and Michael E. Barish' \\ 'Division of Neurosciences, Beckman Research Institute of the City of Hope, Duarte, California 91010, and 2 Department \\ of Biological Science, California State University, Fullerton, California 92634
}

$\mathrm{Na}^{+}-\mathrm{Ca}^{2+}$ exchange has been identified as a mechanism for regulation of intracellular $\mathrm{Ca}$ ion concentration $\left(\left[\mathrm{Ca}^{2+}\right]_{i}\right)$ in neurons of invertebrates and vertebrates, but for mammalian central neurons its role in restoration of resting $\left[\mathrm{Ca}^{2+}\right]_{i}$ after transient increases induced by stimulation has been less clear. We have examined the recovery of $\left[\mathrm{Ca}^{2+}\right]_{i}$ following $\mathbf{K}^{+}$depolarization and glutamate receptor activation of cultured mouse hippocampal neurons using the $\mathrm{Ca}^{2+}$-sensitive dye Fura-2. Reduction of the transmembrane $\mathrm{Na}^{+}$gradient by removal of external $\mathrm{Na}^{+}$slowed the recovery of neurons from imposed $\mathrm{Ca}^{2+}$ loads. We observed that $\left[\mathrm{Ca}^{2+}\right]_{i}$ regulation was disrupted more severely when $\mathbf{N}$-methyl-D-glucamine ( $N-M G)$, Tris, or choline rather than $\mathrm{Li}^{+}$replaced external $\mathrm{Na}^{+}$. Additional disruption of intracellular $\mathrm{pH}$ regulation by substitutes other than $\mathrm{Li}^{+}$may account for this difference. Measurement of $\left[\mathrm{Ca}^{2+}\right]_{i}$ and $\left[\mathrm{H}^{+}\right]_{l}$ (using the $\mathrm{H}^{+}$-sensitive dye BCECF) during glutamate receptor activation indicated that $\mathrm{Ca}^{2+}$ influx resulted in production of intracellular $\mathrm{H}^{+}$, and that $\mathrm{Li}+$ but not $\mathrm{N}-\mathrm{MG}$ could prevent cytoplasmic acidification on removal of external $\mathrm{Na}^{+}$. We also observed that intracellular acidification alone was sufficient to slow recovery from $\mathrm{Ca}^{2+}$ load. We conclude, therefore, that $\mathrm{Na}^{+}-\mathrm{Ca}^{2+}$ exchange contributes to recovery of $\left[\mathrm{Ca}^{2+}\right]$, after stimulation leading to $\mathrm{Ca}^{2+}$ entry into hippocampal neurons, and that $\mathrm{Na}^{+}-\mathrm{H}^{+}$exchange limits the acidification (and secondary increase in $\left[\mathrm{Ca}^{2+}\right]_{i}$ ) that accompanies $\mathrm{Ca}^{2+}$ influx. We suggest that because both $\mathrm{Na}^{+}-\mathrm{Ca}^{2+}$ and $\mathrm{Na}^{+}-\mathrm{H}^{+}$exchangers will be compromised during ischemia and hypoglycemia, increased intracellular $\mathrm{H}^{+}$may synergize with cytoplasmic $\mathrm{Ca}^{2+}$ to potentiate excitotoxic neuronal death.

IKey words: sodium-calcium exchange, sodium-hydrogen exchange, Fura-2, BCECF, intracellular $\mathrm{Ca}^{2+}$ regulation, intracellular $\mathrm{H}^{+}$regulation, hippocampal neurons, mouse]

The processes responsible for restoring intracellular calcium ion concentrations $\left(\left[\mathrm{Ca}^{2+}\right]_{i}\right)$ of neurons to resting levels after stimulation have been divided into three general classes (Blaustein,

\footnotetext{
Received May 14, 1993; revised Sept. 1, 1993; accepted Oct. 14, 1993.

We thank Drs. J. M. Dubinsky and D. W. Hilgemann for helpful discussions about excitotoxicity and $\mathrm{Na}^{+}$-dependent exchangers, Drs. Dubinsky, Hilgemann, and K. J. Seymour-Laurent for their comments on the manuscript, and Mss J. Flanagan and S. Wcbb for assistance in its preparation. Wc also thank $\mathbf{M r}$. P. Steinbach (ETM Systems) for continuing development of VideoProbe. M.E.B. is an Established Investigator of the American Heart Association.

Correspondence should be addressed to Michael E. Barish at the above address.

Copyright (C) 1994 Society for Neuroscience $0270-6474 / 94 / 142585-09 \$ 05.00 / 0$
}

1978, 1988): those involving (1) binding to intracellular sites, (2) sequestration into intracellular organelles, and (3) extrusion into the extracellular space. Mechanisms of $\mathrm{Ca}^{2+}$ extrusion include an ATP-driven $\mathrm{Ca}^{2+}$ pump, and an electrogenic exchange of external $\mathrm{Na}^{+}$for internal $\mathrm{Ca}^{2+}\left(\mathrm{Na}^{+}-\mathrm{Ca}^{2+}\right.$ exchange). The relative contributions of these processes to overall $\mathrm{Ca}^{2+}$ homeostasis vary. This report focuses on the $\mathrm{Na}^{+}-\mathrm{Ca}^{2+}$ exchanger in hippocampal neurons and the consequences of its inhibition by reduction of the transmembrane $\mathrm{Na}^{+}$gradient. Because of their shared dependence on external $\mathrm{Na}^{+}$, intracellular $\mathrm{H}^{+}$and activity of the $\mathrm{Na}^{+}-\mathrm{H}^{+}$exchanger are also considered.

The fundamental properties of the $\mathrm{Na}^{+}-\mathrm{Ca}^{2+}$ exchangers in a variety of cells have been extensively investigated and recently reviewed (Allen et al., 1989; Blaustein et al., 1991a). Less well understood is how the activities of these $\mathrm{Na}^{+}-\mathrm{Ca}^{2+}$ exchangers are integrated into cellular functioning. In neurons, a contribution of $\mathrm{Na}^{+}-\mathrm{Ca}^{2+}$ exchange to regulation of $\left[\mathrm{Ca}^{2+}\right]_{i}$ has been established from investigations of large axons in invertebrates (Baker et al., 1969; Blaustein and Hodgkin, 1969) and of synaptosomes derived from mammalian brain (Blaustein and Wiesmann, 1970).

Herc, we report on the possiblc role of $\mathrm{Na}^{+}-\mathrm{Ca}^{2+}$ exchange in rapid restoration of $\left[\mathrm{Ca}^{2+}\right]_{i}$ to resting levels following increases resulting from depolarization or glutamate receptor activation. $\mathrm{Na}^{+}-\mathrm{Ca}^{2+}$ exchange was inhibited by decrease in $\left[\mathrm{Na}^{+}\right]_{0}$ by substitution with $\mathrm{Li}^{+}, N$-methyl-D-glucamine ( $N$-MG), choline, or Tris. Concentrations of intracellular $\mathrm{Ca}^{2+}$ and $\mathrm{H}^{+}$were measured using the dyes Fura-2 and BCECF. Results of $\left[\mathrm{Ca}^{2+}\right]_{i}$ measurements indicate that in cultured hippocampal neurons the activity of the $\mathrm{Na}^{+}-\mathrm{Ca}^{2+}$ exchanger is important in determining the time course of return of $\left[\mathrm{Ca}^{2+}\right]_{i}$ to resting levels after stimulation. Further, measurements of $\left[\mathrm{H}^{+}\right]_{i}$ suggest that $\mathrm{Ca}^{2+}$ influx imposes an acid load normally buffered by $\mathrm{Na}^{+}-\mathrm{H}^{+}$exchange, and that inhibition of $\mathrm{Na}^{+}-\mathrm{H}^{+}$exchange results in loss of intracellular $\mathrm{pH}$ regulation during periods of $\mathrm{Ca}^{2+}$ influx. We suggest that under conditions in which both $\mathrm{Na}^{+}-\mathrm{Ca}^{2+}$ exchange and $\mathrm{Na}^{+}-\mathrm{H}^{+}$exchange are compromised, as occurs during ischemia and hypoglycemia, cytoplasmic acidification may exacerbate the deleterious effects of excess intracellular $\mathrm{Ca}^{2+}$.

A preliminary report of some of these findings has appeared previously (Koch and Barish, 1991).

\section{Materials and Methods}

Cultures of mouse hippocampal neurons. Timed pregnant female SwissWebster mice were obtained from Simonsen. Cell cultures were prepared using cells dissociated from hippocampi of day 15-16 (E15-E16) em- 


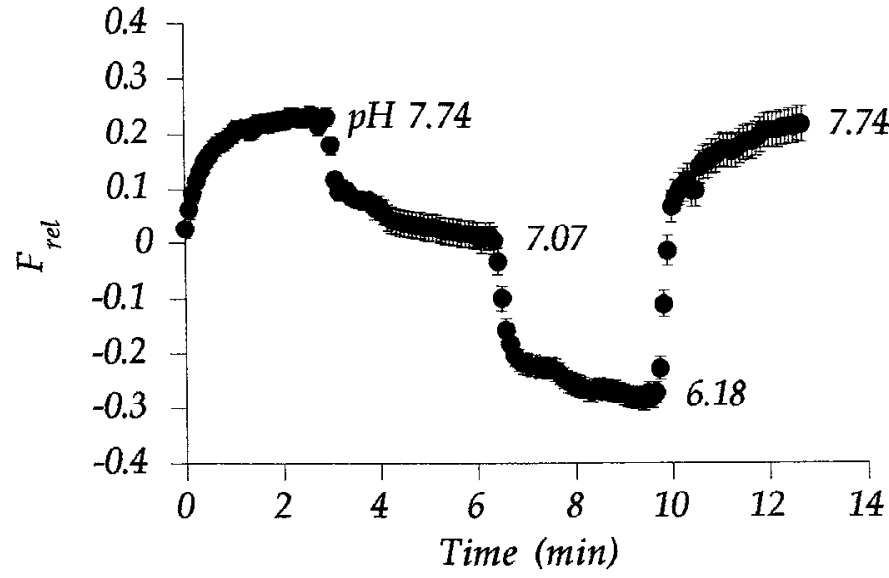

Figure 1. Calibration of BCECF fluorescence and measurement of intracellular $\mathrm{pH}$. Shown is the relative change in fluorescence $\left(F_{\text {rel }} ;\right.$ mean $\pm \mathrm{SEM}, n=36$ cells $)$, where $F_{\text {rel }}=\left(F-F_{0}\right) / F_{0}$. Here, $F$ is the fluorescence at a given time point and $F_{0}$ is the fluorescence at time 0 . Neurons were permeabilized with nigericin $(10 \mu \mathrm{M})$ and superfused with $\mathrm{KCl}$-based external solution buffered with HEPES and PIPES at $\mathrm{pH}_{o}$ of 7.74, 7.07, and 6.18 as indicated. Despite large differences in absolute values of fluorescence (not shown), values of $F_{\text {rel }}$ equilibrated with external $\mathrm{pH}$ within $3 \mathrm{~min}$, and were consistent across many cells.

bryos using procedures described previously (Wu and Barish, 1992). Cells were grown in coverslip chambers constructed by gluing $12-\mathrm{mm}$ diameter Teflon O-rings onto 25 -mm-diameter circular glass coverslips with Sylgard 182 or 184 (Dow Corning) cured by heating on a hot plate. The cover glass surface was coated with $100 \mu \mathrm{g} / \mathrm{ml}$ poly-D-lysine for 1 hr, rinsed threc times with sterile water, and then overlaid with $25 \mu l$ of $12.5 \mu \mathrm{g} / \mathrm{ml}$ laminin in Hank's Balanced Salt Solution (HBSS) for 2$3 \mathrm{hr}$. Aliquots of cells were plated into this solution at concentrations giving final cell densities of 25 or $50 \times 10^{3} \mathrm{cells} / \mathrm{cm}^{2}$. Cultures were treated with antimitotic agents $(10 \mu \mathrm{M}$ fluorodeoxyuridine or cytosine arabinoside) after $1-2 \mathrm{~d}$. Cells were used for experiments after $3-7 \mathrm{~d}$ in culture.

Measurement of intracellular $\mathrm{Ca}^{2+}$ and $\mathrm{H}^{+}$ion concentrations. Procedures for determination of intracellular ion concentrations were similar to those described previously (Barish, 1991). Measurements were made using an inverted fluorescence microscope (Zeiss ICM-405) and an Olympus $40 \times$ UV APO (1.4 NA) objective. Illumination was by a $75 \mathrm{~W}$ xenon bulb and a computer-controlled filter changer in the excitation path (Lambda-10; Sutter Instruments). The microscope was coupled to an intensified CCD camera (Hamamatsu). Images were acquired, analyzed, and intracellular ion concentrations calculated using VideoProbe hardware and software (ETM Systems).

Cells were loaded with Fura-2/AM or BCECF/AM (both from Molecular Probes) in an $\mathrm{Mg}^{2+}$-free HBSS-based loading solution containing (in $\mathrm{mM}$ ) $1.8 \mathrm{CaCl}$ and $25 \mathrm{HEPES}$. For both Fura-2/AM and BCECF/ $\mathrm{AM}$, stocks (1 mM from $50 \mu \mathrm{g}$ aliquots) were dissolved in dry dimethyl sulfoxide (DMSO). For Fura-2, $10 \mu \mathrm{l}$ of Fura-2/AM stock, $10 \mu \mathrm{l}$ of a $10 \%$ Pluronic F-127 aqueous solution, and $20 \mu \mathrm{l}$ of DMSO were added to each milliliter of loading solution. For BCECF, $5 \mu \mathrm{l}$ of BCECF/AM stock was added to each milliliter of loading solution. For both dyes, cells were incubated in loading solution for $1 \mathrm{hr}$ at $37^{\circ} \mathrm{C}$, rinsed with $\mathrm{Mg}$-free HBSS, and then held for a minimum of $2 \mathrm{hr}$ at room temperature to allow for cleavage of the acetoxymethyl (AM) ester.

Fluorescence of the $\mathrm{Ca}^{2+}$-sensitive dye Fura-2 was measured using excitation filters of 350 and $380 \mathrm{~nm}$ (bandwidths of 10 and $13 \mathrm{~nm}$ ), a dichroic mirror at $400 \mathrm{~nm}$, and an emission filter at $510 \mathrm{~nm}$ (bandwidth of $40 . \mathrm{nm}$ ). Intracellular $\mathrm{Ca}^{21}$ was calculated from the ratio $(R)$ of fluorescence emissions $(F)$ at excitation wavelengths of 350 and $380 \mathrm{~nm}$ $\left(F_{350} / F_{380}\right)$ according to the relation (Grynkiewicz et al., 1985)

$$
\left[\mathrm{Ca}^{2+}\right]_{i}=K_{d}\left(F_{380, \text { min }} / F_{380, \text { max }}\right)\left[\left(R-R_{\min }\right) /\left(R_{\max }-R\right)\right],
$$

where the $K_{d}$ for Fura-2 at room temperature was $135 \mathrm{~nm}$ and the subscripts min and max denote values obtained at minimal and saturating concentrations of internal $\mathrm{Ca}^{2+}$. Minimal $\left[\mathrm{Ca}^{2+}\right]_{i}$ was attained after incubating neurons in a $\mathrm{Ca}^{2+}$-free saline containing $5 \mu \mathrm{g} / \mathrm{ml}$ ionomycin and $10 \mathrm{~mm}$ EGTA for $30 \mathrm{~min}$. Saturating $\left[\mathrm{Ca}^{2+}\right]_{i}$ was then obtained by superfusing the same cells with a similar saline containing $5 \mu \mathrm{g} / \mathrm{ml}$ ionomycin and $10 \mathrm{mM} \mathrm{Ca}{ }^{2+}$.

Fluorescence of the $\mathrm{H}^{+}$-sensitive dye BCECF was measured using a standard FITC filter set. Intracellular $\mathrm{H}^{+}$was calculated from the relative change in BCECF fluorescence, $F_{\text {rel }}$, from its initial value $\left(F_{0}\right)$, where

$$
F_{\text {rel }}=\left(F-F_{0}\right) / F_{0}
$$

using the relation

$$
\left[\mathrm{H}^{+}\right]_{i}=K_{d}\left(F_{\text {rel }}-F_{\text {rel, min }}\right) /\left(F_{\text {rel,max }}-F_{\text {rel }}\right) .
$$

Here, $K_{\mathrm{d}}$ for BCECF was $105 \mathrm{nM}$ (calculated from $\mathrm{p} K_{a}=6.98$; Molecular Probes), and $F_{\text {rel.min }}$ and $F_{\text {rel.max }}$ were determined for nigericin-permeabilized neurons ( $10 \mu \mathrm{M}$ nigericin in $\mathrm{KCl}$-based solution) by varying the external pH. We confirmed (Fig. 1) that $F_{\text {rel }}$ remained consistent across many cells and varying absolute intensities of fluorescence as the internal $\mathrm{pH}$ of nigericin-permeabilized neurons was shifted to values spanning the dynamic range of BCECF. When quantitative measurements of $\mathrm{pH}_{i}$ were made, BCECF fluorescence was calibrated by determining $F_{\text {rel,min }}$ and $F_{\text {ret, max }}$ for each field of cells. Cells were permeabilized with nigericin $(10 \mu \mathrm{M})$ and exposed to $\mathrm{KCl}$-based external solutions (containing, in mM, $130 \mathrm{KCl}, 10 \mathrm{NaCl}, 1 \mathrm{MgSO}_{4}, 10 \mathrm{HEPES}, 10$ PIPES) with $\mathrm{pH}$ adjusted to values between 6.0 and 8.0. Nigericin was dissolved in methanol to make a $10 \mathrm{~mm}$ stock, and this stock was diluted 1:1000 into the KCl-based buffer.

Fluorescence images were acquired and stored at $512 \times 512$ pixels. Measurements of fluorescence in individual cells were made by outlining areas of interest over cells identified as neurons based on the presence of high rounded somas and tapering dendrites. Measurements of $\left[\mathrm{Ca}^{2+}\right]_{i}$ were made for neuron somas only, and thus include values for cytoplasm and nucleus and exclude those for dendrites and axons. $\left[\mathrm{Ca}^{2+}\right]_{i}$ in neuronal processes showed qualitatively similar behavior in all experiments, but was not analyzed in detail. Astroglial cells form a thin, flat monolayer under the serum-containing growth conditions employed here, and are easily distinguished from neurons. Synaptic transmission between neurons was not evident in these cultures, probably because cell density was relatively low and the cultures were not allowed to develop for extended periods.

Experimental procedures. The normal external solution was based on HBSS and contained (in mM) $137 \mathrm{NaCl}, 5.4 \mathrm{KCl}, 1.8 \mathrm{CaCl}_{2}, 4.2 \mathrm{NaHCO}_{3}$, 10 HEPES; $\mathrm{pH} 7.3-7.4 ; 300-310 \mathrm{mOsm} / \mathrm{kg}$ (measured with a Wescor vapor pressure osmometer). In $\mathrm{Na}^{+}$-free external solutions, $\mathrm{NaCl}$ was replaced on an equiosmolar basis with (in $\mathrm{mM}$ ) $144 \mathrm{LiCl}, 168 \mathrm{~N}$-methylD-glucamine, 146 choline- $\mathrm{Cl}$, or 144 Tris- $\mathrm{Cl}$ (pH 7.3-7.4; 290-310 $\mathrm{mOsm} / \mathrm{kg}$ in all cases). All solutions contained $0.3 \mu \mathrm{M}$ tetrodotoxin to prevent action potential generation during stimulation. All glutamatecontaining solutions also contained $10 \mu \mathrm{M}$ glycine to maximize activation of NMDA-type glutamate receptors (Johnson and Ascher, 1987).

Solutions were applied using a puffer pipette threaded with five PE10 polyethylene tubes, each connected to a slightly pressurized syringe reservoir. The pipette (orifice diameter of $\sim 100 \mu \mathrm{m}$ ) was positioned approximately $50 \mu \mathrm{m}$ from the cell under study. Normal external solution flowed continuously. To apply test solutions, the valve metering the flow of normal solution was closed at the same time that the valve for the test solution was opened. Solution exchange at the cell required approximately $250 \mathrm{msec}$ as judged by the change in junction potential of a $0.1 \mathrm{M} \mathrm{KCl}-$ filled pipette placed at the cell position as the puffed solution was changed from $0.1 \mathrm{M} \mathrm{KCl}$ to $0.1 \mathrm{M} \mathrm{NaCl}$

All experiments were performed at room temperature $\left(20-22^{\circ} \mathrm{C}\right)$

We observed quantitative differences in the amplitudes and recovery times of $\left[\mathrm{Ca}^{+}\right]_{i}$ responses betwecn batches of culturcs, and accommodated to this variability within individual experiments by comparing control and test responses from the same neurons, and replicating experiments across batches of cultures. Statistical significance within experiments was thus evaluated by paired two-tailed $t$ test on data from individually identified cells. Statistical significance between experiments was evaluated as described in the notes to Tables 1 and 2 . Differences were considered significant at $p<0.05$.

\section{Results}

The stimuli used in this study, either $\mathrm{K}^{+}$or glutamate, were chosen to maximize activation of $\mathrm{Ca}^{2+}$-permeant ion channels. Potassium at 30 or $50 \mathrm{~mm}$ (the usual concentrations employed) would be expected to depolarize the $\left(\mathrm{K}^{+}\right.$-selective) membrane 
$A$
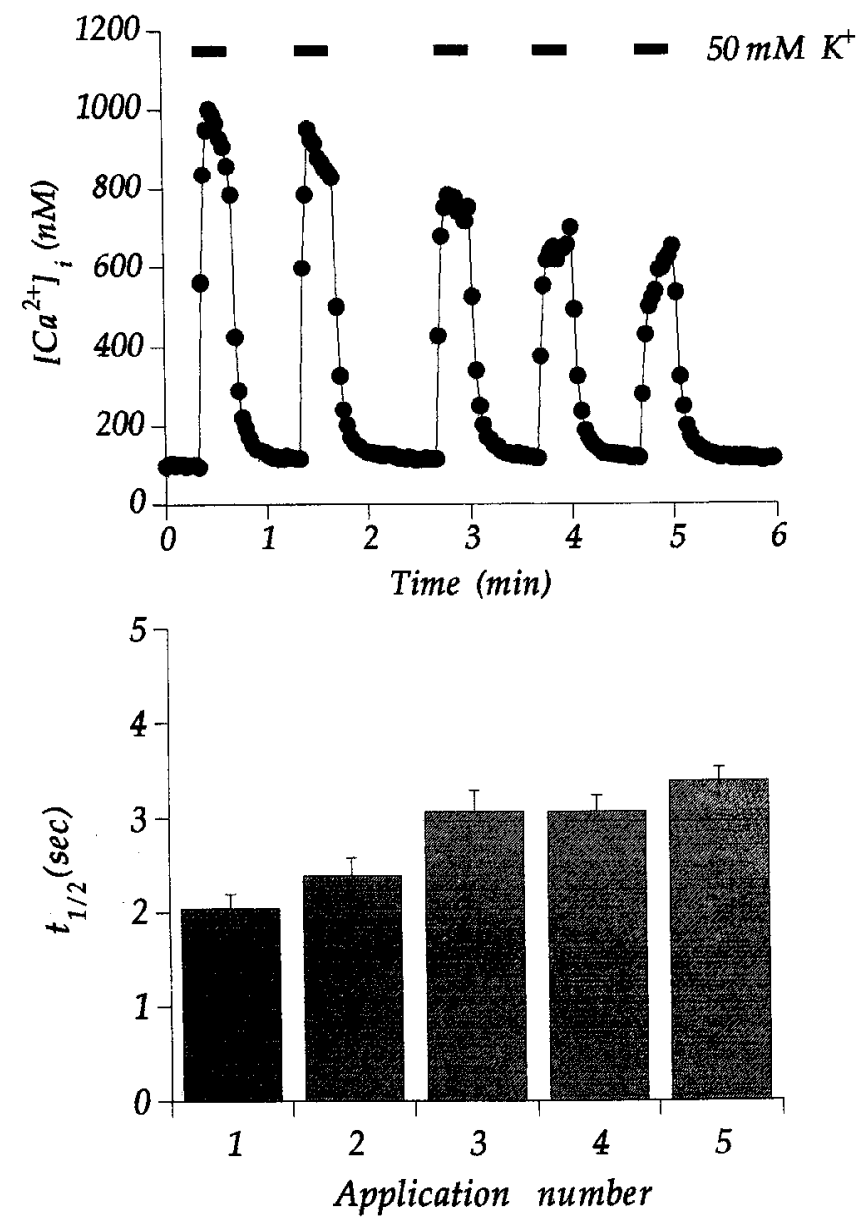

C

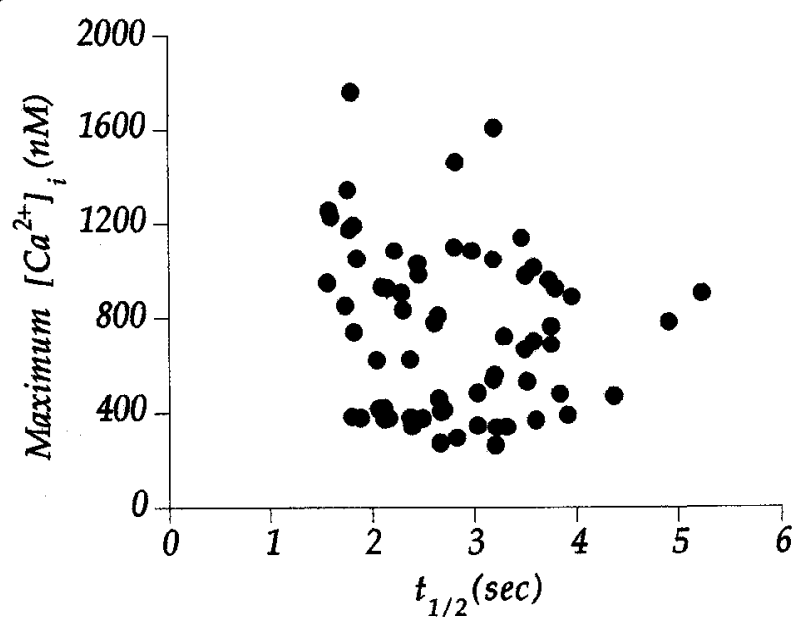

Figure 2. $A,\left[\mathrm{Ca}^{2+}\right]_{i}$ with successive $\mathrm{K}^{+}$depolarizations. Circles represent means ( $n=14$ cells). SEMs were generally smaller than the symbols, and in this and other, similar figures that follow were omitted for clarity. Horizontal bars indicate the period of $50 \mathrm{mM} \mathrm{K}^{+}$application. The decrease in response amplitude was statistically significant $(p<$ 0.0001 , peak 5 vs peak 1$)$. $B$, Half-decay times $\left(t_{1 / 2}\right)$ for $\left[\mathrm{Ca}^{2+}\right]_{i}$ following removal of $50 \mathrm{mM} \mathrm{K} \mathrm{K}^{+}$(mean $\pm \mathrm{SEM}$ ). Tine for half-decay rather than time constant was used as an index of $\left[\mathrm{Ca}^{2+}\right]_{i}$ relaxation time because the return of $\mathrm{Ca}^{2+}$ to baseline was not always exponential (see following figures). For comparison, these control values of $t_{1 / 2}$ are presented using the same vertical scale as used for the experimental data (see Figs. 5, 6 ). The increase in $t_{1 / 2}$ with successive depolarizations was statistically significant when values for cach dcpolarization were compared to those for the first depolarization on a cell-by-cell basis $(p<0.03$, peak 2 vs to approximately -33 or $-15 \mathrm{mV}$ (Barish, 1991) and activate all classes of voltage-gated Ca currents. Glutamate at 20 or 50 $\mu \mathrm{M}$ would be expected to activate both NMDA- and non-NMDAclasses of glutamate receptors (Sands and Barish, 1989; Patneau and Mayer, 1990), and is within the range of extracellular concentrations expected during ischemia (Benveniste, 1991).

The results of control experiments (Fig. 2) established that time courses of recovery of $\left[\mathrm{Ca}^{2+}\right]_{i}$ following repetitive transient stimulations with $\mathrm{K}^{+}$or glutamate were sufficiently stable for the analysis undertaken here, and that the $\mathrm{Ca}^{2+}$ loads imposed by these stimuli could be comfortably buffered by available $\left[\mathrm{Ca}^{2+}\right]_{i}$-regulating mechanisms. After five applications of $50 \mathrm{~mm}$ $\mathrm{K}^{+}-$containing HBSS, the responses of 14 neurons showed a decrease in amplitude of $33 \pm 3 \%$ (mean \pm SEM; Fig. $2 A$ ), while the mean time for $\left[\mathrm{Ca}^{2+}\right]_{i}$ to decline to one-half of the difference between resting and peak concentrations $\left(t_{1 / 2}\right)$ showed a progressive increase over five depolarizations (from $2.04 \pm$ $0.16 \mathrm{sec}$ for the first depolarization to $3.39 \pm 0.13 \mathrm{sec}$ for the fifth; Fig. 2B). While these gradual increases were seen consistently and were statistically significant, they were "well behaved" (i.e., monotonic) and small compared to those induced by substitution for extracellular $\mathrm{Na}^{+}$(compare with Figs. 3, 4). Further, for a given stimulus there was little correlation within a population of neurons between peak response amplitude and $t_{1 / 2}$ recovery (Fig. $2 \mathrm{C}$ ). The results presented in Figure 2 were obtained with $50 \mathrm{mM} \mathrm{K} \mathrm{K}^{+}$as a stimulus; similar results were obtained with other concentrations of $\mathrm{K}^{+}$, and with glutamate stimulation.

\section{Transient stimulation and substitution for external $\mathrm{Na}^{+}$}

$\mathrm{Na}^{+}-\mathrm{Ca}^{2+}$ exchange was blocked by substitution of $\mathrm{Li}^{+}, N-\mathrm{MG}$, choline, or Tris for external $\mathrm{Na}^{+}$. Application of $N$-MG caused a transient elevation of $\left[\mathrm{Ca}^{2+}\right]_{i}$ in 16 of 18 cells. Similar $\left[\mathrm{Ca}^{2+}\right]_{i}$ transients were observed in 8 of 18 cells with choline and 24 of 24 cells with Tris, but were never observed on application of $\mathrm{Li}^{+}$( 0 of 16 cells).

As illustrated in Figure 3, removal of external $\mathrm{Na}^{+}$often reduced the amplitude of the $\left[\mathrm{Ca}^{2+}\right]_{i}$ increase induced by $50 \mathrm{~mm}$ $\mathrm{K}^{+}$, especially for the second application (16 of 16 for $\mathrm{Li}^{+}$on first application; 8 of 8 for $N$-MG on first application; 7 of 12 and 12 of 12 for Tris on first and second applications, respectively; 2 of 18 and 18 of 18 for choline on first and second applications, respectively). As $\mathrm{K}^{+}$depolarization would be expected to activate voltage-gated $\mathrm{Ca}$ channels, the smaller responses could be due to reduction of voltage-gated Ca current by $\mathrm{Na}^{+}$substitution as suggested by Korn and Horn (1989).

Most importantly, substitution for extracellular $\mathrm{Na}^{+}$consistently and reversibly slowed recovery of $\left[\mathrm{Ca}^{2+}\right]_{i}$ after brief $\mathrm{K}^{+}$ depolarizations (Fig. 3, Table $1 ; p<0.0003-0.0001$ for all substitutions). This effect of $\mathrm{Na}^{+}$removal was seen with $\mathrm{Li}$ ' , Tris, $N$-MG, and choline. Since none of these $\mathrm{Na}^{+}$substitutes participate in exchange for internal $\mathrm{Ca}^{2+}$, they might be expected to have similar actions. However, we observed that the magnitudes of the effects seen with $\mathrm{Li}^{+}$substitution (Fig. $3 A$ ) were not as large as those seen with $N-\mathrm{MG}$, Tris, or choline (Fig. $3 B$

peak $1 ; p<0.0001$, peaks 3-5 vs peak 1 ). $C$, Comparison of maximum $\left[\mathrm{Ca}^{2+}\right]_{i}$ attained during $\mathrm{K}^{+}$depolarization versus $t_{1 / 2}$ for its decline. There was little correlation over this series of stimuli between the quantity of $\mathrm{Ca}^{2+}$ that accumulated internally and the time course for its decline (a line of the form $y=-76.32 x+967.85$ could be fit by linear regression, with $r=0.18$ ). Data in $A-C$ were taken from the same cells. 

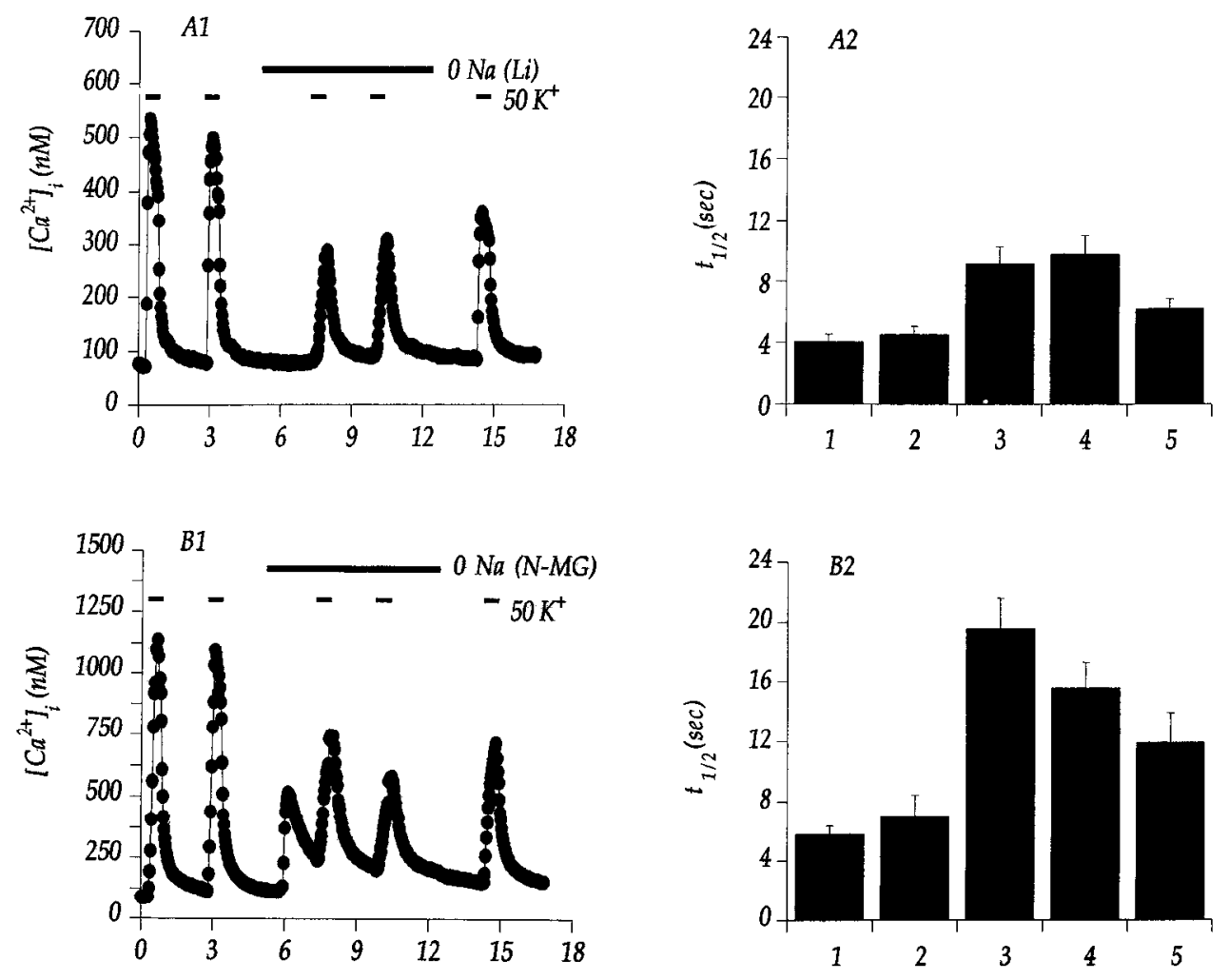

Figure 3. $\left[\mathrm{Ca}^{2+}\right]_{i}$ and time courses of return to resting levels during and aftcr $\mathrm{K}^{+}$depolarizations $(50 \mathrm{~mm})$, in the presence and absence of external $\mathrm{Na}^{+}$. In each portion of the figure, left panels show plots of $\left[\mathrm{Ca}^{2+}\right]_{i}$ versus time and right panels indicate the times required for one-half recovery of resting $\mathrm{Ca}^{2+}$ levels $\left(t_{1 / 2}\right)$ during each period following $\mathrm{K}^{+}$depolarization (the applications of $\mathrm{K}^{+}$-containing solution are sequentially numbered). $A, \mathrm{Na}^{+}$substitution by $\mathrm{Li}^{+} ; B$, substitution by $N-\mathrm{MG} ; C$, substitution by Tris; $D$, substitution by choline. In each plot of $\left[\mathrm{Ca}^{2+}\right]_{i}$ versus timc, bars mark the duration of $\mathrm{K}^{+}$ stimulation $(30 \mathrm{sec})$ and the period of $\mathrm{Na}^{+}$substitution ( $7 \mathrm{~min}$ ), and data points represent means (SEMs were omitted). In bar graphs, the columns show means \pm SEM. Data presented in $A-D$ were taken from cells on sister coverslips derived from the same plating. This procedure was adopted to ensure neurons were not previously exposed to $\mathrm{Na}^{+}$-free solutions. In $B$, values for $t_{1 /}$ ${ }_{2}$ during $\mathrm{Na}^{+}$substitution were measured relative to resting $\left[\mathrm{Ca}^{2+}\right]_{i}$ levels before application of $N$-MG. Numbers of cells were 16 for $\mathrm{Li}^{+}, 8$ for $N-\mathrm{MG}$, 24 for Tris, and 18 for choline.
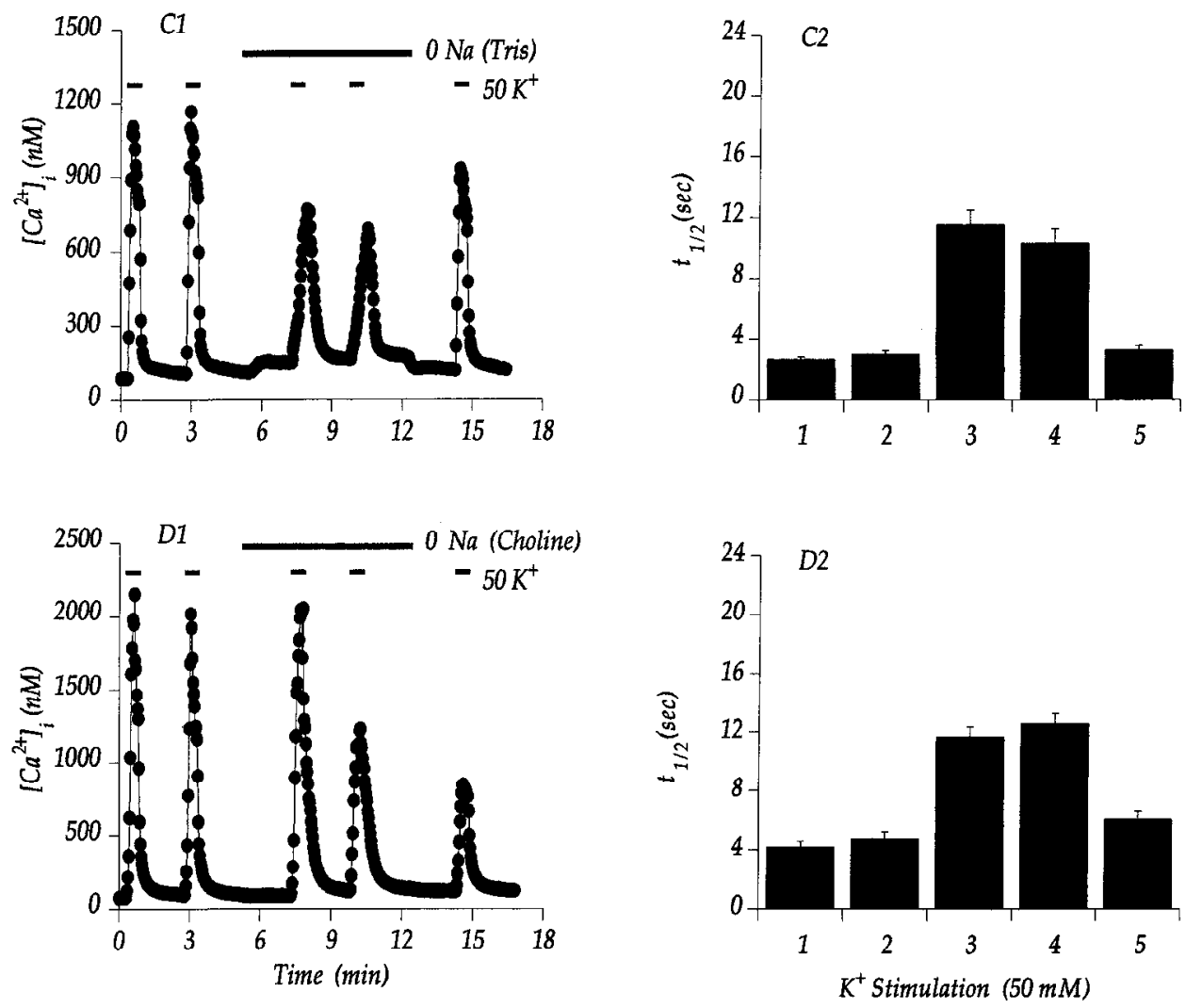

$D$ ). While substitution of $\mathrm{Li}^{+}$for $\mathrm{Na}^{+}$prolonged the recovery of $\left[\mathrm{Ca}^{2+}\right]_{i}$ after $\mathrm{K}^{+}$depolarization by more than twofold, increases in $t_{1 / 2}$ were three- to fourfold when $N$-MG, Tris, or choline was substituted for $\mathrm{Na}^{+}$(although only for Tris was the enhanced effect statistically significant; Table 1).
$\mathrm{Li}^{+}$differs from the other $\mathrm{Na}^{+}$substitutes in that it can substitute for $\mathrm{Na}^{+}$in the $\mathrm{Na}^{+}-\mathrm{H}^{+}$exchanger (see Aronson, 1985). When data derived from the three non- $\mathrm{Li}^{+}$substitutes were combined (a grouping based on the inability of these substitutes to support $\mathrm{Na}^{+}-\mathrm{H}^{+}$exchange) and then compared with data for 
Table 1. Time for one-half decay of intracellular $\mathrm{Ca}^{2+}\left(t_{1 / 2}\right)$ following $\mathrm{K}^{+}$depolarization or glutamate stimulation before and during substitution for external $\mathrm{Na}^{+}$

\begin{tabular}{|c|c|c|c|c|c|c|c|c|}
\hline$\underline{\text { Stimulus }}$ & $\mathrm{Na}^{+}$substitute & $\begin{array}{l}\text { Control } \\
t_{1 / 2}(\mathrm{sec}) \\
\end{array}$ & $\begin{array}{l}t_{1 / 2} \text { with } \\
\text { substitute } \\
\text { (scc) }\end{array}$ & $\begin{array}{l}\text { Mean } t_{1 / 2} \\
\text { ratio (vs } \\
\text { control) } \\
(\mathrm{scc})\end{array}$ & $\begin{array}{l}p \text { vs } \\
\text { control }\end{array}$ & $p$ vs $\mathrm{Li}^{+} \dagger$ & $\begin{array}{l}\text { Mean } t_{1 / 2} \\
\text { ratio (all } \\
\left.\text { non-Li } \mathrm{i}^{+}\right) \\
(\mathrm{sec})\end{array}$ & $p$ vs $\mathrm{Li}^{+} \ddagger$ \\
\hline \multirow[t]{4}{*}{$\mathrm{K}^{+}$depolarization } & $\mathrm{Li}^{+}(n=16)$ & $3.7 \pm 0.3$ & $8.2 \pm 0.7$ & $2.4 \pm 0.2$ & $<0.0001$ & & & \\
\hline & $N$-MG $(n=8)$ & $5.8 \perp 0.6$ & $19.6 \pm 1.9$ & $3.6 \pm 0.5$ & $<0.0003$ & $<0.057$ & & \\
\hline & Tris $(n=24)$ & $2.7 \pm 0.2$ & $11.5 \pm 1.0$ & $4.3 \pm 0.3$ & $<0.0001$ & $<0.0003$ & $3.8 \pm 0.2$ & $<0.0005$ \\
\hline & Choline $(n=17)$ & $4.2 \pm 0.4$ & $11.6 \pm 0.7$ & $3.0 \pm 0.2$ & $<0.0001$ & $<0.4314$ & & \\
\hline \multirow[t]{2}{*}{ Glutamate } & $\mathrm{Li}^{+}(n=16)$ & $6.8 \pm 0.5$ & $63.1 \pm 8.6$ & $10.4 \pm 1.7$ & $<0.0001$ & & & \\
\hline & $N$-MG $(n=15)$ & $8.3 \pm 0.5$ & $114.4 \pm 6.2$ & $13.9 \pm 0.6$ & $<0.0001$ & $<0.062$ & & \\
\hline
\end{tabular}

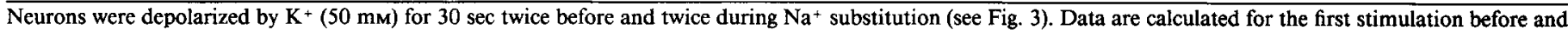
during the test, and are presented as mean \pm SEM.

* Significance evaluated by paired two-tailed $t$ test.

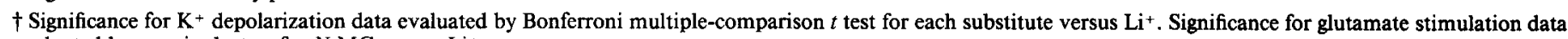
evaluated by unpaired $t$ test for $N$-MG versus $\mathrm{Li}^{+}$.

$\ddagger$ Significance evaluated by unpaired two-tailed $t$ test for all non- $\mathrm{Li}^{+}$substitutes versus $\mathrm{Li}^{+}$.

$\mathrm{Li}^{+}$substitution, the enhanced increase in $t_{1 / 2}$ by non- $\mathrm{Li}^{+}$substitutes was statistically significant (Table $1 ; p<0.0005$ ).

When glutamate receptor activation was used as a stimulus, $t_{1 / 2}$ for recovery of $\left[\mathrm{Ca}^{2+}\right]_{i}$ after stimulation also showed large reversible increases during substitution for external $\mathrm{Na}^{+}$(Fig. 4 , Table 1). Because a secondary increase in $\left[\mathrm{Ca}^{2+}\right]_{i}$ was observed following removal of glutamate under $\mathrm{Na}^{+}$-substituted conditions, the relative increases in $t_{1 / 2}$ were larger than seen with $\mathrm{K}^{+}$ depolarization (10-14-fold). As was seen for $\mathrm{K}^{+}$depolarization, $t_{1 / 2}$ recovery was consistently longer with $N$-MG rather than $\mathrm{Li}^{+}$ substitution (although it did not quite reach statistical significance, $p<0.062 \mathrm{vs} \mathrm{Li}^{+}$). The secondary increase was also more pronounced in the presence of the non- $\mathrm{Li}^{+}$substitute.

The data presented in Figures 3 and 4 are representative of
20 experiments on neurons in culture for 3-10 d from E15-E16 embryos in which $\mathrm{Li}^{+}, N-\mathrm{MG}$, choline, or Tris was used as substitute for external $\mathrm{Na}^{+}$during stimulation by $50 \mathrm{~mm} \mathrm{~K} \mathrm{~K}^{+}$or $20 \mu \mathrm{M}$ glutamate. Removal of external $\mathrm{Na}^{+}$resulted in delayed recovery of $\left[\mathrm{Ca}^{2+}\right]_{i}$ in every instance, and in cases in which the effects of $\mathrm{Na}^{+}$substitution with $\mathrm{Li}^{+}$were compared to those of substitution with $N$-MG, Tris, or choline, the effects of large cations were always more pronounced.

\section{Intracellular $\mathrm{Ca}^{2+}$ and $\mathrm{H}^{+}$concentrations during continuous glutamate receptor activation}

We compared the effects of substitution of external $\mathrm{Na}^{+}$with $\mathrm{Li}^{+}$or $N-\mathrm{MG}$ on both $\left[\mathrm{Ca}^{2+}\right]_{i}$ and $\left[\mathrm{H}^{+}\right]_{i}$ during continuous glutamate receptor activation. $\left[\mathrm{Ca}^{2+}\right]_{i}$ and $\left[\mathrm{H}^{+}\right]_{i}$ were measured
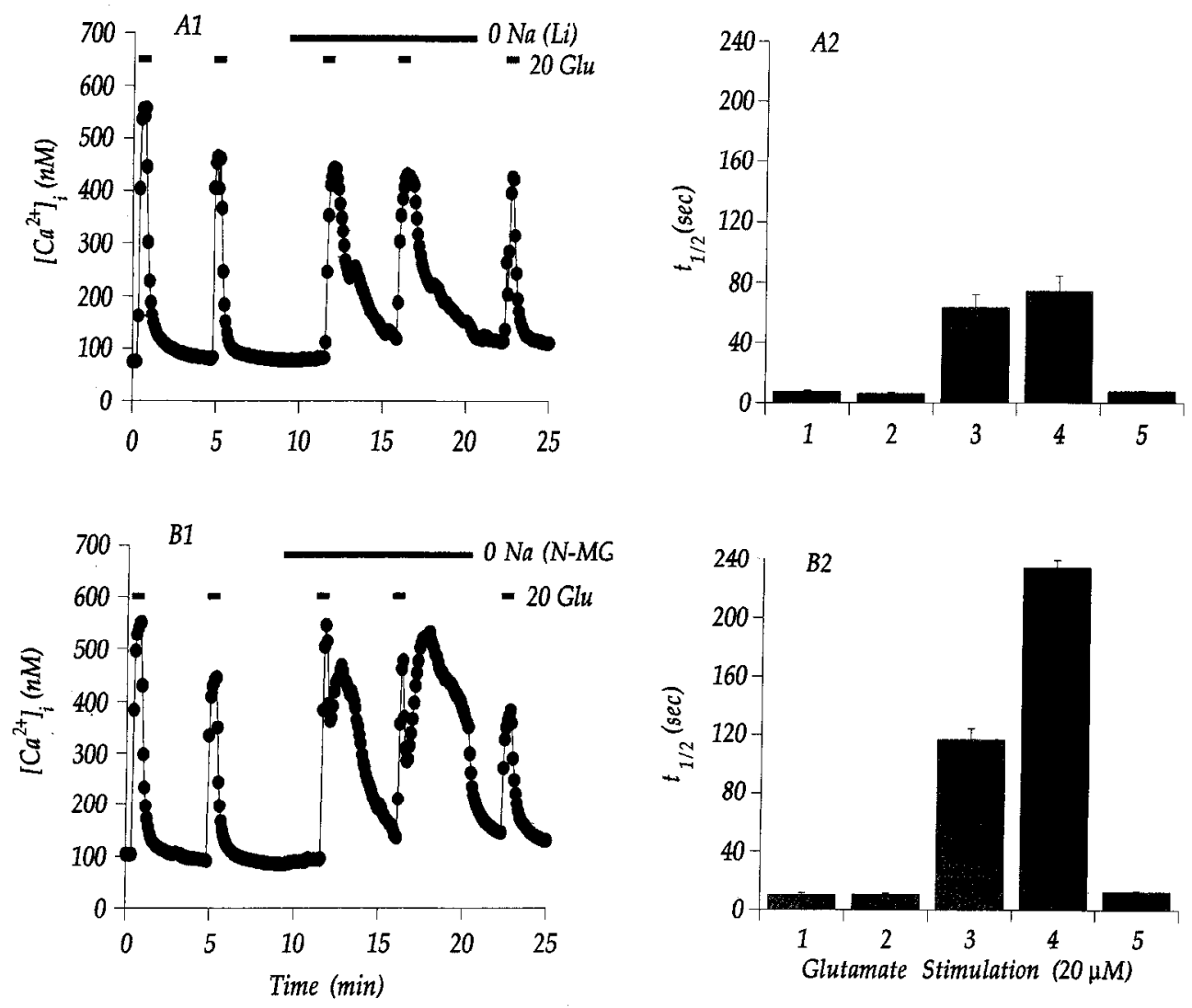

Figure 4. $\left[\mathrm{Ca}^{2+}\right]_{i}$ and time courses of its recovery during and after glutamate receptor activation $(20 \mu \mathrm{M})$, in the presence and absence of external $\mathrm{Na}^{+}$. The data are presented as in Figure 3. $A$, $\mathrm{Na}^{+}$substitution by $\mathrm{Li}^{+} ; B$, substitution by $N$-MG. Sister coverslips were used. In the left panels data points represent means; in the right panels the columns show mean \pm SEM. Numbers of cells were 17 for $\mathrm{Li}^{+}$and 22 for $N$-MG. 


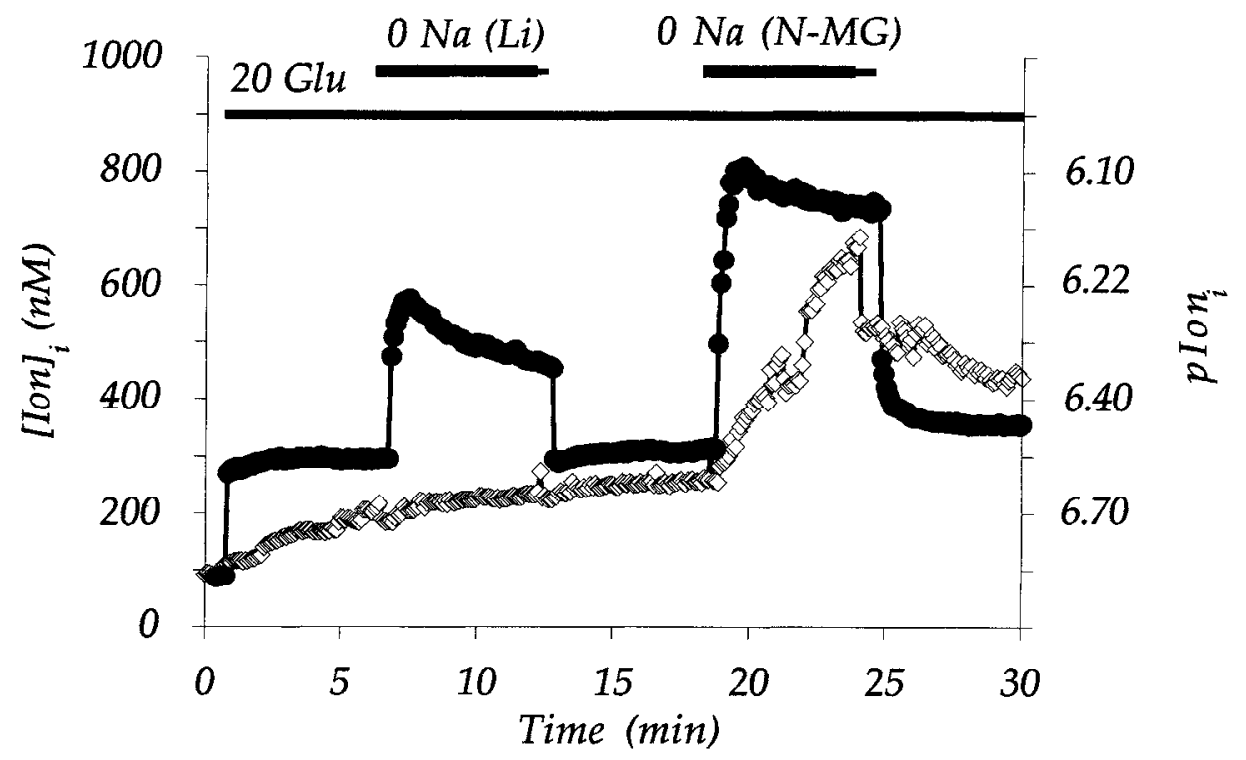

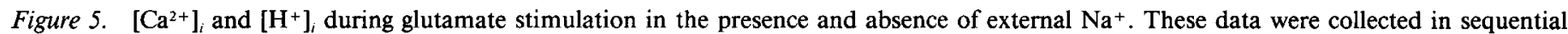
experiments from neurons on sister coverslips from the same plating. Solid circles represent $\left[\mathrm{Ca}^{2+}\right]_{i}$ and open diamonds represent $\left[\mathrm{H}^{+}\right]_{i}$ as measured in $\mathrm{nM}$ against the left vertical scale and as $\mathrm{pCa}$ and $\mathrm{pH}$ on the right vertical scale. The lower horizontal bar indicates the duration of glutamate stimulation $(20 \mu \mathrm{M})$ and the upper horizontal bars mark the $6 \mathrm{~min}$ intervals of substitution for $\mathrm{Na}^{+}$. Data points represent means; means \pm SEM are noted in the Results for resting and peak values. The times of transitions from one solution to another differed by a few seconds in the two experiments; for accuracy in presentation of the data, the thick portions of the horizontal bars apply to the $\left[\mathrm{H}^{+}\right]_{i}$ data, and the narrow portions represent the additional time during which $\mathrm{Na}^{+}$-free conditions existed in the $\left[\mathrm{Ca}^{2+}\right]_{i}$ experiment. Numbers of cells analyzed were 24 for $\left[\mathrm{Ca}^{2+}\right]_{i}$ and 36 for $\left[\mathrm{H}^{+}\right]_{i}$.

from sister coverslips under identical ionic conditions (Fig. 5). Data are shown plotted on vertical scales indexed in both linear (molar concentration) and negative logarithmic (pIon) units.

While substitution of $\mathrm{Li}^{+}$or $N-\mathrm{MG}$ for external $\mathrm{Na}^{+}$had qualitatively similar effects on $\left[\mathrm{Ca}^{2+}\right]_{i}$, the effects of $N$-MG were more severe. Resting $\left[\mathrm{Ca}^{2+}\right]_{i}$ was $88.9 \pm 0.4 \mathrm{~nm}$, and this was rapidly increased to a stable value of $292 \pm 0.8 \mathrm{nM}$ by application of $20 \mu \mathrm{M}$ glutamate ( $n=24$ cells). Substitution of $\mathrm{Li}^{+}$for $\mathrm{Na}^{+}$(in the continued presence of glutamate) resulted in an increase to a peak value of $578 \pm 49 \mathrm{~nm}$ that relaxed toward a steady state $(504 \pm 4.0 \mathrm{nM})$ and that returned to its resting value on return of external $\mathrm{Na}^{+}$. Subsequent replacement of $\mathrm{Na}^{+}$by $N$-MG resulted in a larger increase to a peak of $810 \pm 22 \mathrm{nM}$ that relaxed more slowly (steady state value, $756 \pm 3.7 \mathrm{nM}$ ) and that reversed less completely on return to $\mathrm{Na}^{+}$-containing solution.

$\mathrm{Li}^{+}$and $N$-MG had markedly different effects on the slow acidification induced by application of $20 \mu \mathrm{M}$ glutamate. Resting $\mathrm{pH}_{i}$ was $7.03 \pm 0.01$ ( $\sim 93 \mathrm{nM}$; mean $\pm \mathrm{SEM}, n=36$ cells $)$. The initial application of glutamate (in $\mathrm{Na}^{+}$-containing solution) triggered a slow fall in $\mathrm{pH}_{i}$ to $6.71 \pm 0.28(\sim 195 \mathrm{nM})$ after 6 min. Substitution of $\mathrm{Li}^{+}$for $\mathrm{Na}^{+}$and reintroduction of $\mathrm{Na}^{+}$had minimal if any effect on this slow acidification. In contrast, substitution with $N$-MG elicited a rapid fall in $\mathrm{pH}_{i}$ to $6.16 \pm$ $0.27(\sim 692 \mathrm{nM})$ by the conclusion of the $6 \mathrm{~min}$ period of exposure to $\mathrm{Na}^{+}$-free solution. Subsequently, $\left[\mathrm{H}^{+}\right]_{i}$ only partially recovered during $6 \mathrm{~min}$ in $\mathrm{Na}^{+}$-containing solution.

A similar pattern of effects on intracellular $\mathrm{Ca}^{2+}$ and $\mathrm{H}^{+}$regulation was seen in 8 of 8 experiments comparing $\mathrm{Li}^{+}$with $N-\mathrm{MG}$ as $\mathrm{Na}^{+}$substitutes.

\section{Intracellular acidification and recovery from $\mathrm{Ca}^{2+}$ load}

Because our data suggested that some substitutions for external $\mathrm{Na}^{+}$could result in enhanced accumulation of $\mathrm{H}^{+}$during $\mathrm{Ca}^{2+}$ influx, we examined whether intracellular acidification would itself slow the return of $\left[\mathrm{Ca}^{2+}\right]_{i}$ to resting levels after glutamate stimulation. In this experiment, recovery of $\left[\mathrm{Ca}^{2+}\right]_{i}$ was compared before and during exposure to acidic external solution containing $10 \mathrm{~mm}$ lactate. Exploratory experiments established that application of this solution caused intracellular $\mathrm{pH}$ to fall to approximately 6.6 after $16 \mathrm{~min}$. We observed that intracellular acidification resulted in a greater than twofold increase in $t_{1 / 2}$ after exposure to $20 \mu \mathrm{M}$ glutamate (Table 2).

\section{Discussion}

Reduction in the inward driving force on $\mathrm{Na}^{+}$will affect at least two mechanisms acting in parallel, $\mathrm{Na}^{+}-\mathrm{Ca}^{2+}$ exchange and $\mathrm{Na}^{+}-\mathrm{H}^{+}$exchange. Our data indicate that inhibition of the $\mathrm{Na}^{+}-$ $\mathrm{Ca}^{2+}$ exchange alone will compromise intracellular $\mathrm{Ca}^{2+}$ regulation, and that intracellular acidification also retards recovery of $\left[\mathrm{Ca}^{2+}\right]_{i}$ after stimulation. Thus simultaneous inhibition of $\mathrm{Na}^{+}-\mathrm{Ca}^{2+}$ and $\mathrm{Na}^{+}-\mathrm{H}^{+}$exchangers will disrupt $\mathrm{Ca}^{2+}$ homeostasis both directly and indirectly.

That the effects of substitution for external $\mathrm{Na}^{+}$involved the $\mathrm{Na}^{+}-\mathrm{Ca}^{2+}$ exchanger rather than some other mechanism (such as alteration of second messenger systems by $\mathrm{Li}^{+}$; Berridge and Irvine, 1989) is indicated by the rapid onset and reversibility of the delay in recovery of $\left[\mathrm{Ca}^{2+}\right]_{i}$ by $\mathrm{Na}^{+}$substitutes, and the qualitative similarity of the effects of $\mathrm{Li}^{+}, N-\mathrm{MG}$, choline, and Tris. The additional influence of $\mathrm{pH}_{i}$ on $\left[\mathrm{Ca}^{2+}\right]_{i}$ regulation was indicated by comparison of the effects of substitution with $\mathrm{Li}^{+}$ versus $N$-MG. Cytoplasmic acidification accompanied $\mathrm{Na}^{+}$substitution by $N$-MG but not by $\mathrm{Li}^{+}$during glutamate receptor activation, and we observed in other experiments that acidification of the cytoplasm (using external lactate) resulted in delays in recovery of $\left[\mathrm{Ca}^{2+}\right]_{i}$ after stimulation.

Thus, we suggest that the effects of $N-\mathrm{MG}$, Tris, or choline substitution on $\left[\mathrm{Ca}^{2+}\right]_{i}$ regulation were always more severe than 
those seen with $\mathrm{Li}^{+}$because, in addition to blockade of $\mathrm{Na}^{+}-$ $\mathrm{Ca}^{2+}$ exchanger, the acid load accompanying $\mathrm{Ca}^{2+}$ intlux could not be dissipated by the $\mathrm{Na}^{+}-\mathrm{H}^{+}$exchanger. The additional intracellular $\mathrm{Ca}^{2+}$ seen with $\mathrm{N}$-MG substitution, for example (Fig. 5), may reflect the contribution of $\mathrm{Ca}^{2+}$ displaced from cytoplasmic binding sites by excess $\mathrm{H}^{+}$(Rose and Rick, 1978; Dickens et al., 1989), or partial inhibition of remaining $\mathrm{Ca}^{2+}$ regulating mechanisms.

Viewed from another perspective, the results reported here emphasize the care with which substitutes for external $\mathrm{Na}^{+}$must be chosen. Choline and $N-\mathrm{MG}$ are commonly employed in investigations of putative activities of $\mathrm{Na}^{+}-\mathrm{Ca}^{2+}$ exchange. As they also profoundly altered intracellular $\mathrm{pH}$ regulation in the face of increase in $\left[\mathrm{Ca}^{2+}\right]_{i}$, a role of $\mathrm{H}^{+}$in effects commonly attributed to cytoplasmic $\mathrm{Ca}^{2+}$ and inhibition of $\mathrm{Na}^{+}-\mathrm{Ca}^{2+}$ exchange should also be considered.

\section{$\mathrm{Na}^{+}-\mathrm{Ca}^{2+}$ exchange in neuronal $\mathrm{Ca}^{2+}$ regulation}

A role of the $\mathrm{Na}^{+}-\mathrm{Ca}^{2+}$ exchanger in regulation of neuronal $\left[\mathrm{Ca}^{2+}\right]_{i}$ was first appreciated for large invertebrate axons and synaptosomes (see introductory remarks). $\mathrm{Na}^{+}-\mathrm{Ca}^{2+}$ exchange has been characterized as a low-affinity and high-capacity mechanism for extrusion of cytoplasmic $\mathrm{Ca}^{2+}$. In general, the present results are consistent with the conclusion of other studies that $\mathrm{Na}^{+}-\mathrm{Ca}^{2+}$ exchange is less important for regulation of basal $\left[\mathrm{Ca}^{2+}\right]_{i}$ levels but more significant at elevated $\mathrm{Ca}^{2+}$ concentrations.

The results of several recent experimental efforts support $\mathrm{Na}^{+}$-dependent $\mathrm{Ca}^{2+}$ efflux as a mechanism of recovery from transient intracellular $\mathrm{Ca}^{2+}$ load in Aplysia neurons (Levy and Tillotson, 1988), rat brain synaptosomes (Nachshen, 1985; Nachshen et al., 1986; Taglialatela et al., 1990), pituitary cell lines (Korn and Weight, 1987; Korn and Horn, 1989), neuroblastoma and pheochromocytoma cells (Dickens et al., 1989), and presynaptic terminals at crayfish and squid synapses (Zipser ct al., 1991; Mulkey and Zucker, 1992), as well as in cultured rat hippocampal neurons (Blaustein et al., 1991b; Segal and Manor, 1992). In these studies, removal of external $\mathrm{Na}^{+}$resulted in delayed restoration of resting levels of $\left[\mathrm{Ca}^{2+}\right]_{i}$ in the seconds immediately following stimulation when this was determined by using $\mathrm{Ca}^{2+}$-sensitive dyes, $\mathrm{Ca}^{2+}$-activated $\mathrm{Cl}^{-}$current, or ${ }^{45} \mathrm{Ca}^{2+}$ flux. Taken together with the results reported here, these studies made using different detection methodologies indicate that $\mathrm{Na}^{+}-\mathrm{Ca}^{2+}$ exchange can participate in dynamic regulation of neuronal intracellular $\mathrm{Ca}^{2+}$ over periods of seconds to minutes during and immediately following stimulation.

The contribution of $\mathrm{Na}^{+}-\mathrm{Ca}^{2+}$ exchange to regulation of $\left[\mathrm{Ca}^{2+}\right]_{i}$ transients may not be universal. In several investigations of peripheral sensory neurons (cultured rat dorsal root ganglion neurons: Benham et al., 1989; Thayer and Miller, 1990; acutely dissociated mouse dorsal root ganglion neurons: Duchen et al., 1990), little evidence was obtained for a contribution of $\mathrm{Na}^{+}-$ $\mathrm{Ca}^{2+}$ exchange to restoration of $\left[\mathrm{Ca}^{2+}\right]_{i}$ to resting levels following stimulation. This difference may reflect variation in the contribution of $\mathrm{Na}^{+}-\mathrm{Ca}^{2+}$ exchange to overall $\left[\mathrm{Ca}^{2+}\right]_{i}$ regulation in different cells, and/or a consistent difference in mechanisms of intracellular $\mathrm{Ca}^{2+}$ regulation between central and peripheral neurons.

\section{$\mathrm{Na}^{+}-\mathrm{H}^{+}$exchange and neuronal $\mathrm{H}^{+}$regulation}

We measured $\mathrm{pH}_{i}$ in unstimulated hippocampal neurons to be approximately 7.03 , a value similar to that obtained in other
Table 2. Time for one-half decay of intracellular $\mathrm{Ca}^{2+}\left(t_{1 / 2}\right)$ following glutamate stimulation before and during intracellular acidification

Lactate

$(n=9)$

Control $t_{1 / 2}$ before acidification (sec)

$83 \pm 0.7$

$t_{1 / 2}$ during acidification (sec)

Mean $t_{1 / 2}$ ratio (vs control) (sec)

$19.2 \pm 4.0$

$p$ vs control

$2.3 \pm 0.4$

$<0.02$

Neurons were stimulated by glutamate $(20 \mu \mathrm{M})$ for $30 \mathrm{sec}$ before and during intracellular acidification imposed by application of HBSS containing $10 \mathrm{~mm}$ lactate. Data are presented as mean \pm SEM. Significance was evaluated using paired two-tailed $t$ test as for Table 1 . Results of identical parallel experiments in which intracellular $\mathrm{pH}$ was measured using BCECF indicate that lactate shifted $\mathrm{pH}_{i}$ from $7.22 \pm 0.10$ to $6.62 \pm 0.08$ after 16 min of equilibration (mean $\pm \mathrm{SEM}$, $n=12$ ).

studies of hippocampal and other neurons (see Chesler, 1990, for review). Our data are consistent with the results of studies indicating the importance of $\mathrm{Na}^{+}-\mathrm{H}^{+}$exchange in regulation of intracellular $\mathrm{pH}$ in cultured rat hippocampal neurons (RaleySusman et al., 1991), rat brain synaptosomes (Nachshen and Drapeau, 1988), cultured sympathetic neurons (Tolkovsky and Richards, 1987), and identified leech neurons (Deitmer and Schlue, 1988).

Our results extend this previous work by emphasizing the role of the $\mathrm{Na}^{+}-\mathrm{II}^{+}$exchanger in extrusion of the acid generated by glutamate receptor activation. In the experiment illustrated in Figure $5,\left[\mathrm{H}^{+}\right]_{i}$ increased steadily during a period of $\mathrm{Na}^{+}-\mathrm{H}^{+}$ exchange inhibition in the face of steady glutamate-induced $\mathrm{Ca}^{2+}$ influx. In $\mathrm{Na}^{+}$-free external solution, $\left[\mathrm{Ca}^{2+}\right]_{i}$ and $\left[\mathrm{H}^{+}\right]_{i}$ reached almost identical levels (approximately $810 \mathrm{~nm}$ for $\mathrm{Ca}^{2+}$ and 692 for $\mathrm{H}^{+}$), and $\left[\mathrm{H}^{+}\right]_{i}$ continued to increase even after 6 min. $\mathrm{Ca}^{2+}$ accumulation at the inner surface of the cell membrane will displace $\mathrm{H}^{+}$from intracellular sites and induce local acidification (Meech and Thomas, 1977, 1980; Ahmed and Connor, 1980), and the $\mathrm{Na}^{+}-\mathrm{H}^{+}$exchanger may provide a rapid and localized mechanism for extrusion of this $\mathrm{H}^{+}$. If $\mathrm{Na}^{+}-\mathrm{H}^{+}$ exchange was impaired during a period of prolonged $\mathrm{Ca}^{2+}$ influx (as during ischemia), our results suggest the $\mathrm{H}^{+}$concentration of the cytosol could exceed that of $\mathrm{Ca}^{2+}$.

\section{Relevance to the physiology of hippocampal neurons}

Electrophysiology. In principle, the activity of the $\mathrm{Na}^{+}-\mathrm{Ca}^{2+}$ exchanger may influence the fring properties of neurons by two different mechanisms: (1) by regulating the $\mathrm{Ca}^{2+}$ concentration at the inner surface cell membrane in the vicinity of $\mathrm{Ca}^{2+}$ dependent ion channels, and (2) by electrogenic production of depolarizing current. While neither of these possibilities has been investigated in hippocampal neurons, the rate of $\mathrm{Ca}^{2+}$ clearance by $\mathrm{Na}^{+}-\mathrm{Ca}^{2+}$ exchange influences the time course of a slow afterhyperpolarization in bullfrog sympathetic ganglion (Goh et al., 1992; see also Korn and Horn, 1989), and electrogenic $\mathrm{Na}^{+}-\mathrm{Ca}^{2+}$ exchange current is responsible for a slow depolarizing afterpotential in neocortical neurons (Friedman et al., 1992). Similar processes may operate in hippocampal neurons.

Further, $\mathrm{Na}^{+}-\mathrm{Ca}^{2+}$ exchange may participate in activity-dependent modulation of transmitter release by influencing $\left[\mathrm{Ca}^{2+}\right]_{i}$ in presynaptic terminals. In presynaptic terminals at crayfish neuromuscular junction, inhibition of $\mathrm{Na}^{+}-\mathrm{Ca}^{2+}$ exchange by increase in internal $\mathrm{Na}^{+}$or by substitution of $\mathrm{Li}^{+}$for external 
$\mathrm{Na}^{+}$prolonged the decay of both $\left[\mathrm{Ca}^{2+}\right]_{i}$ and postsynaptic potential amplitude following tetanic stimulation (posttetanic potentiation; Mulkey and Zucker, 1992).

Excitotoxicity. We noted a striking similarity in the concentrations of $\mathrm{Ca}^{2+}$ and $\mathrm{H}^{+}$during glutamate stimulation (approaching $1 \mu \mathrm{M}$ ) if $\mathrm{Na}^{+}$-dependent mechanisms of $\mathrm{Ca}^{2+}$ and $\mathrm{H}^{+}$ extrusion were blocked (Fig. 5). Episodes of cerebral ischemia and hypoglycemia are accompanied by a decrease in intracellular ATP, increase in intracellular $\mathrm{Na}^{+}$, and increase in extracellular $\mathrm{H}^{+}$(Nedergaard et al., 1990). Inhibition of $\mathrm{Ca}^{2+}$ and $\mathrm{H}^{\prime}$ transport may result, as (1) both the $\mathrm{Na}^{+}-\mathrm{Ca}^{2+}$ (see DiPolo and Beaugé, 1983, 1991; Collins et al., 1992) and $\mathrm{Na}^{+}-\mathrm{H}^{+}$ (Cassel et al., 1986; Weissberg et al., 1989) exchangers are positively regulated by internal ATP, (2) $\mathrm{Na}^{+}-\mathrm{H}^{+}$exchange is inhibited by external $\mathrm{H}^{+}$(see Aronson, 1985), and (3) both exchangers are inhibited by a rise in cytoplasmic $\mathrm{Na}^{+}$. Thus, during the initial period of ischemia and hypoglycemia characterized by high concentrations of glutamate in extracellular space, both $\mathrm{Na}^{+}-\mathrm{Ca}^{2+}$ and $\mathrm{Na}^{+}-\mathrm{H}^{+}$exchangers may be compromised.

An increase in $\left[\mathrm{H}^{+}\right]_{i}$ in parallel with $\left[\mathrm{Ca}^{2+}\right]_{i}$ during ischemia and hypoglycemia could result in significant cellular damage. Our data indicate that exposure to a moderate concentration of glutamate $(20 \mu \mathrm{M})$ can lower $\mathrm{pH}_{i}$ to below 6.15 in only a few minutes if $\mathrm{Na}^{+}-\mathrm{H}^{+}$exchange is impaired. This value of $\mathrm{pH}_{i}$ is well within the toxic range for neurons (Nedergaard et al., 1991). While lactic acid accumulation is often considered the mechanism of intracellular acidosis in ischemia (see Plum, 1983), $\mathrm{H}^{+}$ accumulation may also occur as a consequence of $\mathrm{Ca}^{2+}$-dependent displacement of $\mathrm{H}^{+}$from shared binding sites and reduced $\mathrm{Na}^{+}-\mathrm{H}^{+}$exchange. Evidence consistent with this possibility was presented by Pirttilä and Kauppinen (1992), who observed in brain slice that complexing extracellular $\mathrm{Ca}^{2+}$ in $\mathrm{Na}^{+}$-free medium reduced acidification during anoxia. In addition to being itself toxic (Nedergaard et al., 1991), intracellular $\mathrm{H}^{\prime}$ could also synergize with $\mathrm{Ca}^{2+}$ in causing neuronal damage and death by several concurrently activated pathways (see Tombaugh and Sapolsky, 1990a), including displacement of $\mathrm{Ca}^{2+}$ from intracellular binding sites and blockade of several classes of potassium channels that normally act to stabilize membrane potential (see Moody, 1984).

While excitotoxicity is often considered dependent on $\mathrm{Ca}^{2+}$ entry (Choi, 1987), the magnitude of glutamate-induced increase in $\left[\mathrm{Ca}^{2+}\right]_{i}$ is often not preciscly correlated with cell death when these are tallied for individual cells (Michaels and Rothman, 1990; Dubinsky and Rothman, 1991; but see Ogura et al., 1988; de Erausquin et al., 1990). Thus, an additional process consequent on glutamate receptor activation and $\mathrm{Ca}^{2+}$ influx may be involved (Choi, 1990; Choi and Rothman, 1990), and increased intracellular $\mathrm{H}^{+}$could be such an additional factor. As described, regulation of both $\left[\mathrm{Ca}^{2+}\right]_{i}$ and $\left[\mathrm{H}^{+}\right]_{i}$ will be affected during ischemia and hypoglycemia, and glutamate receptor activation will impose strong $\mathrm{H}^{+}$and $\mathrm{Ca}^{2+}$ loads. This notion is particularly attractive because studies proposing a role of $\mathrm{Na}^{+}-$ $\mathrm{Ca}^{2+}$ exchange in protection from excitotoxic insult (Mattson et al., 1989a; Mattson, 1990) have been performed using $\mathrm{Na}^{+}$ substitutions (e.g., choline) that will also block $\mathrm{Na}^{+}-\mathrm{H}^{+}$exchange. It has been further proposed that growth factors may increase the ability of hippocampal neurons to tolerate a glutamate- or hypoglycemia-induced $\mathrm{Ca}^{2+}$ load (Mattson et al., 1989b; Mattson and Rychlik, 1990; Cheng and Mattson, 1991) by increasing the activity of $\mathrm{Na}^{+}$-dependent extrusion of internal $\mathrm{Ca}^{2+}$ (Mattson, 1990). As stimulating actions of growth fac- tors on $\mathrm{Na}^{+}-\mathrm{H}^{+}$exchange are well known for non-neuronal cells (for reviews, see Moolenaar et al., 1986; Grinstein et al., 1989), it may be that growth factor-induced potentiation of $\mathrm{Na}^{+}-\mathrm{H}^{+}$ exchange (possibly compromised by a fall in [ATP] ${ }_{i}$ ) enhances the ability of cells to buffer $\mathrm{H}^{+}$displaced by $\mathrm{Ca}^{2+}$ during accumulation to excitotoxic concentrations.

These potentially toxic actions of strong intracellular acidification exist in contrast to the neuroprotective effects of mild extracellular acidification (Giffard et al., 1990; Tombaugh and Sapolsky, 1990b; Takadera et al., 1992), which appear to be a consequence of block of the NMDA class of glutamate receptor by external $\mathrm{H}^{+}$(Giffard et al., 1990; Tang et al., 1990; Traynelis and Cull-Candy, 1990; Vyklický et al., 1990).

\section{References}

Ahmed Z, Connor JA (1980) Intracellular pH changes induced by calcium influx during electrical activity in molluscan neurons. J Gen Physiol 75:403-426.

Allen TJA, Noble D, Reuter H, eds (1989) Sodium-calcium exchange. New York: Oxford UP.

Aronson PS (1985) Kinetic properties of the plasma membrane $\mathrm{Na}^{+}-$ $\mathrm{H}^{+}$exchanger. Annu Rev Physiol 47:545-560.

Baker PF, Blaustein MP, Hodgkin AL, Steinhardt RA (1969) The influence of sodium concentration on calcium movements in giant axons. J Physiol (Lond) 200:431-458.

Barish ME (1991) Increases in intracellular calcium ion concentration during depolarization of cultured embryonic Xenopus spinal neurones. J Physiol (Lond) 444:545-565.

Benham CD, Evans ML, McBain CJ (1989) Inhibition of Ca-ATPase slows recovery from voltage-gated $\mathrm{Ca}_{i}$ load in cultured neurones from rat dorsal root ganglia. J Physiol (Lond) 415:21P.

Benveniste $H(1991)$ The excitotoxin hypothesis in relation to cerebral ischemia. Cerebrovasc Brain Metab Rev 3:213-245.

Berridge MJ, Irvine RF (1989) Inositol phosphates and cell signalling. Nature 341:197-205.

Blaustein MP (1978) Calcium and synaptic function. Handb Exp Pharmacol 83:275-304.

Blaustein MP (1988) Calcium transport and buffering in neurons. Trends Neurosci 11:438-442.

Blaustein MP, Hodgkin AL (1969) The effect of cyanide on the efflux of calcium from squid axons. J Physiol (Lond) 200:497-527.

Blaustein MP, Wiesmann WP (1970) Effect of sodium ions on calcium movements in isolated synaptic terminals. Proc Natl Acad Sci USA 66:664-671.

Blaustein MP, DiPolo R, Reeves JP, eds (1991a) Annals of the New York Academy of Sciences, Vol 639, Proceedings of the Second International Conference: Sodium-calcium exchange. New York: NY Academy of Sciences.

Blaustein MP, Goldman WF, Fontana G, Krueger BK, Santiago EM, Steele TD, Weiss DN, Yarowsky PJ (1991b) Physiological roles of the sodium-calcium exchanger in nerve and muscle. Ann NY Acad Sci 639:254-274.

Cassel D, Katz M, Rotman M (1986) Depletion of cellular ATP inhibits $\mathrm{Na}^{+} / \mathrm{H}^{+}$antiport in cultured human cells. J Biol Chem 261: 5460-5466.

Cheng B, Mattson MP (1991) NGF and bFGF protect rat hippocampal and human cortical neurons against hypoglycemic damage by stabilizing calcium homeostasis. Neuron 7:1031-1041.

Chesler M (1990) The regulation and modulation of $\mathrm{pH}$ in the nervous system. Prog Neurobiol 34:401-427.

Choi DW (1987) Ionic dependence of glutamate neurotoxicity. J Neurosci 7:369-379.

Choi DW (1990) Cerebral hypoxia: some new approaches and unanswered questions. J Neurosci 10:2493-2501.

Choi DW, Rothman SM (1990) The role of glutamate neurotoxicity in hypoxic-ischemic neuronal death. Annu Rev Neurosci 13:171182.

Collins A, Somlyo AV, Hilgemann DW (1992) The giant cardiac membrane patch method: stimulation of outward $\mathrm{Na}^{+}-\mathrm{Ca}^{2+}$ exchange current by MgATP. J Physiol (Lond) 454:27-57.

de Erausquin GA, Manev H, Guidotti A, Costa E, Brooker G (1990) Gangliosides normalize distorted single-cell intracellular free $\mathrm{Ca}^{2+}$ 
dynamics after toxic doses of glutamate in cerebellar granule cells. Proc Natl Acad Sci USA 87:8017-8021.

Deitmer JW, Schlue W-R (1988) Intracellular acidosis of identified leech neurones produced by substitution of external sodium. Brain Res 462:233-241.

Dickens CJ, Gillespie JI, Greenwell JR (1989) Interactions between intracellular $\mathrm{pH}$ and calcium in single mouse neuroblastoma (1N2A) and rat pheochromocytoma cells (1PC12). Q J Exp Physiol 74:671679.

DiPolo R, Beaugé L (1983) The calcium pump and sodium-calcium exchange in squid axons. Annu Rev Physiol 45:313-324.

DiPolo R, Beaugé L (1991) Regulation of Na-Ca exchange. Ann NY Acad Sci 639:100-111.

Dubinsky JM, Rothman SM (1991) Intracellular calcium concentrations during "chemical hypoxia" and excitotoxic neuronal injury. J Neurosci 11:2545-2551.

Duchen MR, Valdeolmillos M, O'Neill SC, Eisner DA (1990) Effects of metabolic blockade on the regulation of intracellular calcium in dissociated mouse sensory neurones. J Physiol (Lond) 424:411-426.

Friedman A, Arens J, Heinemann U, Gutnick MJ (1992) Slow depolarizing afterpotentials in neocortical neurons are sodium and calcium dependent. Neurosci Lett 135:13-17.

Giffard RG, Monyer H, Christine CW, Choi DW (1990) Acidosis reduces NMDA receptor activation, glutamate neurotoxicity, and oxygen-glucose deprivation neuronal injury in cortical cultures. Brain Res 506:339-342.

Goh JW, Sanches-Vives MV, Pennefather PS (1992) Influence of $\mathrm{Na}$ / $\mathrm{Ca}$ exchange and mobilization of intracellular calcium on the time course of the slow afterhyperpolarization current $\left(I_{\mathrm{AHP}}\right)$ in bullfrog sympathetic ganglion neurons. Neurosci Lett 138:123-127.

Grinstein S, Rotin D, Mason MJ (1989) $\mathrm{Na}^{+} / \mathrm{H}^{+}$exchange and growth factor-induced cytosolic $\mathrm{pH}$ changes. Role in cellular proliferation. Biochem Biophys Acta 988:73-97.

Johnson JW, Ascher P (1987) Glycine potentiates the NMDA response in cultured mouse brain neurons. Naturc 325:529-531.

Koch RA, Barish ME (1991) Sodium-calcium exchange in cultured embryonic mouse hippocampal neurons. J Cell Biol 115:22a.

Korn SJ, Horn R (1989) Influence of sodium-calcium exchange on calcium current rundown and the duration of calcium-dependent chloride currents in pituitary cells, studied with whole cell and perforated patch recording. J Gen Physiol 94:789-812.

Korn SJ, Weight FF (1987) Patch-clamp study of the calcium-dependent chloride current in AtT-20 pituitary cells. J Neurophysiol 58: 1431-1451.

Levy S, Tillotson D (1988) Effects of $\mathrm{Na}^{+}$and $\mathrm{Ca}^{2+}$ gradients on intracellular free $\mathrm{Ca}^{2+}$ in voltage-clamped Aplysia neurons. Brain Res 474:333-342.

Mattson MP (1990) Excitatory amino acids growth factors, calcium: a teeter-totter model for neural plasticity, and degeneration. Adv Exp Med Biol 268:211-220.

Mattson MP, Rychlik B (1990) Glia protect hippocampal neurons against excitatory amino acid-induced degeneration: involvement of fibroblast growth factor. Int J Dev Neurosci 8:399-415.

Mattson MP, Guthrie PB, Kater SB (1989a) A role for $\mathrm{Na}^{+}$-dependent $\mathrm{Ca}^{2+}$ extrusion in protection against neuronal excitotoxicity. FASEB J 3:2519-2526.

Mattson MP, Murrain M, Guthrie PB, Kater SB (1989b) Fibroblast growth factor and glutamate: opposing roles in the generation and degeneration of hippocampal neuroarchitecture. J Neurosci 9:37283740.

Meech RW, Thomas RC (1977) The effect of calcium injection on the intracellular sodium and $\mathrm{pH}$ of snail neurones. J Physiol (Lond) 265: 867-879.

Meech RW, Thomas RC (1980) Effect of measured calcium chloride injections on the membrane potential and internal $\mathrm{pH}$ of snail neurons. J Physiol (Lond) 298:111-129.

Michaels RL, Rothman SM (1990) Glutamate neurotoxicity in vitro: agonist pharmacology and intracellular calcium concentrations. J Neurosci 10:283-292.

Moody W Jr (1984) Effects of intracellular $\mathrm{H}^{+}$on the electrical propcrtics of excitable cells. Annu Rev Neurosci 7:257-278.

Moolenaar WH, Defize LHK, De Laat SW (1986) Ionic signalling by growth factor receptors. J Exp Biol 124:359-373.

Mulkey RM, Zucker RS (1992) Posttetanic potentiation at the crayfish neuromuscular junction is dependent on both intracellular calcium and sodium ion accumulation. J Neurosci 12:4327-4336.
Nachshen DA (1985) Regulation of cytosolic calcium concentration in presynaptic nerve endings isolated from rat brain. J Physiol (Lond) 363:87-101.

Nachshen DA, Drapeau P (1988) The regulation of cytosolic pH in isolated presynaptic nerve terminals from rat brain. J Gen Physiol 91:289-303.

Nachshen DA, Sanchez-Armass S, Weinstein AM (1986) The regulation of cytosolic calcium in rat brain synaptosomes by sodiumdependent calcium efflux. J Physiol (Lond) 381:17-28.

Nedcrgaard M, Kraig RP, Tanabc J, Pusinclli WA (1990) Dynamics of interstitial and intracellular pH in evolving brain infarct. Am $J$ Physiol 260:R581-R588.

Nedergaard M, Goldman SA, Desai S, Pusinelli WA (1991) Acidinduced death in neurons and glia. J Neurosci 11:2489-2497.

Ogura A, Miyamoto M, Kudo Y (1988) Neuronal death in vitro: parallelism between survivability of hippocampal neurones and sustained elevation of cytosolic $\mathrm{Ca}^{2+}$ after exposure to glutamate receptor agonist. Exp Cell Res 73:447-458.

Patneau DK, Mayer ML (1990) Structure-activity relationships for amino acid transmitter candidates at $N$-methyl-D-aspartate and quisqualate receptors. J Neurosci 10:2385-2399.

Pirttilä T-RM, Kauppinen RA (1992) Recovery of intracellular pH in cortical brain slices following anoxia studied by nuclear magnetic resonance spectroscopy: role of lactate removal, extracellular sodium and sodium/hydrogen exchange. Neuroscience 47:155-164.

Plum F (1983) What causes infarction in ischemic brain? The Robert Wartenberg lecture. Neurology 33:222-233.

Raley-Susman KM, Cragoe EJ, Sapolsky RM, Kopito RR (1991) Regulation of intracellular $\mathrm{pH}$ in cultured hippocampal neurons by an amiloride-insensitive $\mathrm{Na}^{+} / \mathrm{H}^{+}$exchanger. J Biol Chem 266:27392745.

Rose B, Rick R (1978) Intracellular $\mathrm{pH}$, intracellular free $\mathrm{Ca}$, and junctional cell-cell coupling. J Membr Biol 44:377-415.

Sands SB, Barish ME (1989) A quantitative description of excitatory amino acid neurotransmitter responses on cultured embryonic Xenopus spinal neurons. Brain Res 502:375-386.

Segal M, Manor D (1992) Confocal microscopic imaging of $\left[\mathrm{Ca}^{2+}\right]_{i}$ in cultured rat hippocampal neurons following exposure to $N$-methylD-aspartate. J Physiol (Lond) 448:655-676.

Taglialatela M, Di Renzo G, Annunziato L (1990) $\mathrm{Na}^{+}-\mathrm{Ca}^{2+}$ exchange activity in central nerve endings. I. Ionic conditions that discriminate ${ }^{45} \mathrm{Ca}^{2+}$ uptake through the exchanger from that occurring through voltage-operated $\mathrm{Ca}^{2+}$ channels. Mol Pharmacol 38:385-392.

Takadera T, Shimada Y, Mohri T (1992) Extracellular pH modulates $N$-methyl-D-aspartate receptor-mediated neurotoxicity and calcium accumulation in rat cortical cultures. Brain Res 572:126-131.

Tang C-M, Dichter M, Morad M (1990) Modulation of the $N$-methylD-aspartate channel by extracellular $\mathrm{H}^{+}$. Proc Natl Acad Sci USA 87: 6445-6449.

Thayer SA, Miller RJ (1990) Regulation of the intracellular free calcium concentration in single rat dorsal root ganglion neurones in vitro. J Physiol (Lond) 425:85-115.

Tolkovsky AM, Richards CD (1987) $\mathrm{Na}^{+} / \mathrm{Ca}^{+}$exchange is the major mechanism of $\mathrm{pH}$ regulation in cultured sympathetic neurons: measurements in single cell bodies and neurites using a fluorescent $\mathrm{pH}$ indicator. Neuroscience 22:1093-1102.

Tombaugh GC, Sapolsky RM (1990a) Mechanistic distinctions between excitotoxic and acidotic hippocampal damage in an in vitro model of ischemia. J Cereb Blood Flow Metab 10:527-535.

Tombaugh GC, Sapolsky RM (1990b) Mild acidosis protects hippocampal neurons from injury induced by oxygen and glucose deprivation. Brain Res 506:343-345.

Traynelis SF, Cull-Candy SG (1990) Proton inhibition of $N$-methylD-aspartate receptors in cerebellar neurons. Nature 345:347-350.

Vyklický L Jr, Vlachová V, Krưšek J (1990) The effect of external pH changes on responses to excitatory amino acids in mouse hippocampal neurones. J Physiol (Lond) 430:497-517.

Weissberg PL, Little PJ, Cragoe FJ Jr, Bobik A (1989) The pH of spontaneously beating cultured rat heart cells is regulated by an ATP. calmodulin-dependent $\mathrm{Na}^{+} / \mathrm{H}^{+}$antiport. Circ Res 64:676-685.

Wu R-L, Barish ME (1992) Two pharmacologically and kinetically distinct transient potassium currents in cultured embryonic mouse hippocampal neurons. J Neurosci 12:2235-2246.

Zipser K, Augustine GJ, Deitmer J (1991) $\mathrm{Na}$ /Ca exchange regulates presynaptic calcium levels. Biophys J 59:594a. 